\title{
CONDECORACIÓN CÉSAR URIBE PIEDRAHITA AL DR. JOSÉ IGNACIO HERNÁNDEZ CRUZ Sesión solemne, octubre 3 de 2014
}

\author{
Palabras del Dr. Germán Fernández Cabrera*
}

El Colegio Médico de Cundinamarca es la institución gremial médica más antigua de Colombia con 98 años de existencia. De su seno surgió la Federación Médica Colombiana, que como entidad de orden superior, agrupa a los Colegios Médicos Departamentales, entidad que registró hace unos meses la celebración de su cumpleaños número 78.

Estamos aquí reunidos, en el Auditorio Guillermo Fergusson Manrique del Hospital de San José en sesión solemne, para imponer la máxima condecoración que otorga nuestro Colegio a un distinguido colega, cuyo ejercicio profesional ha sido digno, honesto, ético y al servicio de los intereses de la salud de los colombianos.

En estos tiempos turbulentos, en donde el capital financiero arremete contra todas las instituciones de la salud y la seguridad social que en su desarrollo histórico había logrado Colombia, la actitud honorable y enhiesta de los condecorados por el Colegio Médico de Cundinamarca y Bogotá sirve de ejemplo para todas las generaciones de colegas y de profesionales del sector de la salud. Y ese es uno de los motivos por los cuales honramos al Profesor Hernández hoy día.

También resaltamos en él la dedicación a su propia causa, que ha sido inspiradora para quienes hemos compartido en su grata compañía trayectos de la vida estudiantil, laboral, gremial o las luchas por un sistemá de salud más justo para los colombianos.

Honrando el nombre de la condecoración y para quienes no lo conocen, evoco la memoria del memorable científico César Uribe Piedrahita, nacido en Medellín en 1896. Estudió medicina en la Universidad de Antioquia y se especializó en la Universidad de Harvard, en 1921. Estando en los Estados Unidos de Norteamérica publicó algunos trabajos sobre protozoarios y parasitología en revistas especializadas.

* Presidente del Colegio Médico de Cundinamarca, Colombia.

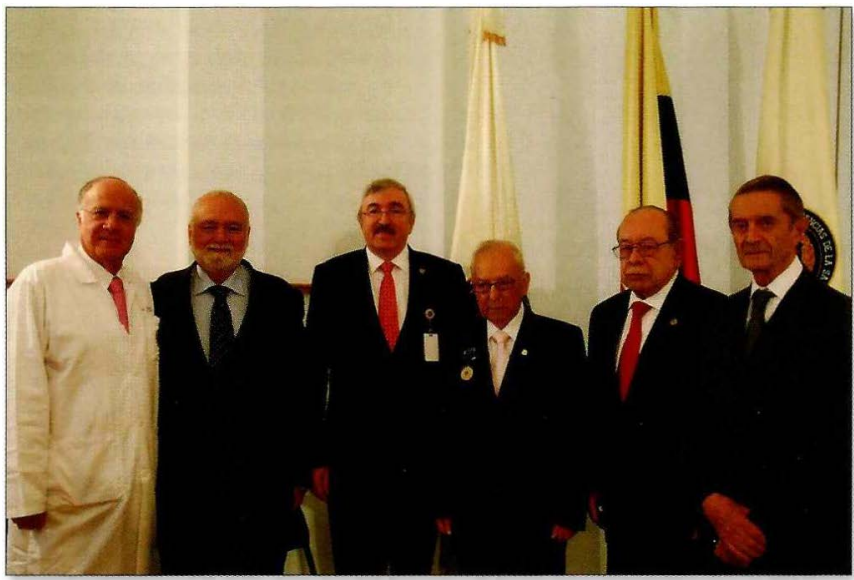

Ceremonia de la condecoración César Uribe Piedrahita. Aparecen de izquierda a derecha los doctores Luis A. Blanco, Germán Fernández, Jorge Gómez, José Ignacio Hernández, Dario Cadena y Francisco Pardo.

Al regresar a Colombia fue nombrado director del Instituto Nacional de Higiene, institución predecesora del Ministerio de Higiene, cuya creación fue promovida posteriormente, en 1940, por la Federación Médica Colombiana. En el ejercicio de su cargo, realizó diversos viajes por el país, impulsando el desarrollo de una de las mayores colecciones de flora y fauna. Durante estos viajes, además, aprendió varias lenguas aborígenes, por sus naturales capacidades lingüísticas.

Desarrolló el primer antídoto contra el veneno de serpiente en Colombia. También ejerció como profesor en la Universidad de Antioquia, donde estudió las estructuras nucleares y patologías de enfermedades dermatológicas. En la Universidad Nacional de Colombia fundó el departamento de parasitología. Entre 1931 y 1932 fue rector de la Universidad del Cauca en Popayán, donde emprendió varias iniciativas como cambios modernizadores en la estructura universitaria, la actualización de los laboratorios y las bibliotecas, la educación sexual de los jóvenes y la defensa del ejercicio al aire libre. 
Dirigió y fundó varios centros de investigación, y fue miembro fundador de la Academia Nacional de Ciencias y del Herbario Nacional. Polifacético, de espíritu independiente. Curioso y aventurero, escritor de novelas de gran sentido social como Toá y Mancha de Aceite, fue cercano en su juventud al grupo de artistas y literatos de "Los Pánidas". Sabía tocar el violín y realizó pintura y escultura en madera, artes de las que hizo algunas exposiciones en Bogotá.

En la época en la que vivió, los ecos de las revoluciones sociales ocasionadas por la primera guerra mundial, sobrevenidas cuando contaba veinte años de edad, propiciaron que una parte considerable de los intelectuales y artistas hispanoamericanos tomaran conciencia de las vejaciones que oprimían a las clases menos favorecidas. Ello generó un amplio movimiento político y social tendiente a la construcción de una nueva sociedad en la que quedaron abolidas las grandes diferencias, corriente en la que debe insertarse todo el trabajo creativo, y aun la labor científica, de César Uribe Piedrahita.

En su obra literaria compuesta por dos novelas, un relato, y los fragmentos de una tercera narración extensa que quedó inconclusa en el momento de su muerte, postula la creación de una nueva sociedad en la que sea posible la construcción del "hombre nuevo", un ser libre de la tiranía y la opresión que, en dichas novelas, quedan encarnadas en el feroz dominio de las grandes compañías.

Fue fundador de los laboratorios CUP. Tres años antes de su desaparición, César Uribe había sufrido la pérdida de miles de anotaciones en las que atesoraba algunas de sus más importantes observaciones científicas, recogidas a lo largo de toda su brillante trayectoria como especialista en parasitología y toxicología. Tal desgracia ocurrió el 9 de abril de 1948, cuando los disturbios sociales y políticos que estallaron en Bogotá provocaron, entre otros graves incidentes, un incendio que acabó con los famosos laboratorios CUP, fundados por el propio Uribe y bautizados con las siglas de su nombre.

Estuvo casado con Lucrecia Uribe Lince y no tuvo descendencia. Su muerte acaecida en 1951, cuando contaba con 54 años de edad, se le atribuye a su cer- cana amistad con las copas, proximidad que cobró su precio.

Por los innegables méritos de este científico y profesor, la Federación Médica Colombiana estableció, desde hace muchos años, que los Colegios Médicos Departamentales honrarían a los colegas de su jurisdicción con esta categorizada distinción, la que imponemos gustosos en esta ocasión solemne.

El sector de la salud por medio de sus diversas organizaciones viene, desde hace tiempo, manifestando sus razonas de franco descontento con el acontecer azaroso en los servicios de salud. Hasta ahora, no ha habido respuesta por parte del Gobierno Nacional que atienda las insistentes peticiones para modificar de manera sustancial la estructura del fracasado Sistema de Salud, representadas en solicitudes presentadas por las diversas organizaciones. En cualquier caso, seguiremos insistiendo en nuestra causa, que es la causa de todos los colombianos.

Nuestro Colegio ha exaltado tradicionalmente cada año a muy contados colegas. El año 2012, exaltamos a dos connotados médicos. Dadas las circunstancias actuales en las que cerca de 30.000 colegas viven en la jurisdicción de Cundinamarca y Bogotá, nos ha parecido lo más justo ampliar el número de exaltados para no ser omisos o exiguos con trabajos de toda una vida y dedicación que merecen ser difundidos. Y con mayor razón en las épocas difíciles que enfrentamos los profesionales y trabajadores de la salud. Así fue que en 2013 condecoramos a seis distinguidos galenos. En este año 2014, en decisión unánime de nuestro Colegio Médico de Cundinamarca y Bogotá, se les ha conferido la condecoración César Uribe Piedrahita a los siguientes colegas: José Ignacio Hernández Cruz, Odilio Méndez Sandoval y Juan Manuel Anaya Cabrera.

Entregamos hoy con orgullo y satisfacción al respetado y querido profesor y amigo José Ignacio Hernández Cruz la distinción que le reconoce sus méritos y su dedicación en las diferentes áreas del saber y del actuar en las que se ha desempeñado, particularmente por su meritoria labor docente formadora de muchas generaciones de médicos, de las cuales orgullosamente formo parte.

Muchas gracias profesor. 